Royal Irish Academy:

New Professor of Theoretical Physics

Aт the election meeting of the Royal Irish Academy in Dublin on March 16, it was announced that Dr. Erwin Schrödinger had been appointed professor of theoretical physies in the Academy as from April 1. The funds for the professorship are being supplied to the Academy by the Irish Government. Prof. Schrödinger has been giving a course of lectures on wave mechanics at University College, Dublin, since November last. This course has had a large attendance from members of the two Dublin Colleges. It will be continued now in the Royal Irish Academy.

It is believed that the institution of this professorship is intended as a temporary measure, pending the setting up of an institute for theoretical physics in Dublin, in which Prof. Schrödinger will have a permanent appointment. The recent publication of the text of a Bill making provision for the new institute shows that Mr. de Valera does not intend the financial difficulties arising out of the War situation to upset his plans for the development of higher mathematical studies. In addition to mathematics and theoretical physics, the mention of cosmology, geophysics and even chemistry in the Bill may be taken as indicating that Mr. de Valera has in mind the possibility of the institute broadening the scope of its studies in the future. There is also to be an institute for the promotion of higher Celtic studies.

\section{Prof. H. Arctowski}

Wiтн home, laboratory, and invaluable records of years presumably irrevocably lost during the War, Prof. Henryke Aretowski, formerly honorary professor of geophysies and meteorology in the University of Lwow, has begun work at the Smithsonian Institution on the direct effects of changes in the sun's radiation on weather conditions on the earth. Prof. Arctowski is recognized as one of the greatest authorities on world weather. $\mathrm{He}$ has now started with renewed enthusiasm on the correlation of solar and terrestrial phenomena from the comprehensive records of the Smithsonian Astrophysical Observatory. He has already made significant-although for the present tentative-findings of apparent causeand-effect relationships between the variation of solar radiation and terrestrial weather conditions.

\section{John Dixon Mann}

Dr. Јоhn Dixon Mann, an eminent Manchester toxicologist, was born in 1840 at Kendal, where his father was borough treasurer. $\mathrm{He}$ received his medical education at the Manchester Royal School of Medicine and qualified M.R.C.S. and L.S.A. in 1862. For many subsequent years he was engaged in general practice in Manchester, but in 1880 he became M.R.C.P.(Lond.) as well as M.D. of St. Andrews, and confined himself to consultant practice. In 1882 he was appointed physician to the Salford Royal Hospital, and three years later became lecturer in forensic medicine and toxicology at Owens College, Manchester, in succession to Dr. C. J.
Cullingworth, who was elected professor of obstetries and gynæcology. The lectureship was converted into a chair in 1892. Dixon Mann's principal work, "Forensic Medicine and Toxicology", which won him the Swiney Prize awarded by the Royal College of Physicians of London and the Society of Arts, went through four editions between 1893 and 1907 and was for many years the standard work on the subject. His other book, entitled "On the Physiology and Pathology of the Urine with Methods for its Examination", appeared in 1904 and was followed by a second edition in 1908. He also made numerous contributions to periodical medical literature including the Medical Chronicle, the now extinct Manchester journal, which contains a bibliography of his writings. He died on April 6, 1912.

\section{Hindu and Moslem in India}

The course of recent events in India tends to confirm apprehension, such as has found expression in the columns of Nature from time to time while the terms of the new constitution were under consideration, lest the introduction of the forms of Western democracy among a population of so heterogeneous a character in culture, creed and tradition might encounter difficulties well-nigh insuperable. It was hoped by those responsible for decision that the communal solution would at once secure the rights of minorities and ensure their acquiescence in the rule of the majority which is essential for the successful working of dəmocratic institutions. It has been made evident by subsequent events that the necessary community of outlook was lacking. This is to be seen on one side in the breakdown under provincial autonomy, on the other in the difficulty in formulating a scheme of federation in which the claims of democracy can be reconciled with the autocracy of the native States and the fears of the Princes lest they should endanger rights based upon tradition and further secured by the treaty with the British Crown.

A situation which bristles with difficulties and requires the most delicate handling has been brought within measurable distance of a crisis in the turmoil of world events. The Indian Congress, the representative body of the Hindu community, has seized the opportunity to put forward a claim for the grant of that independent status for India towards which it was hoped the new constitution would serve both as a stage and a training ground. This claim the Moslem League has countered by a demand for the recognition of separate Moslem and Hindu nations within the bounds of India. The demand is by no means so fantastic as it may appear at first. Apart from the fact that the voice of a minority of some eighty millions or more, sectional differences for once forgotten, cannot be ignored, it is based upon a very real difference in a cultural tradition, as every student of Indian civilization is aware ; for the Moslem tradition fosters a democratic outlook while fearing and resenting a Hindu domination in an independent India, which would from its immemorial tradition of caste be essentially oligarchic in practice. However impracticable the Moslem demand may be, no 